\title{
Variety is the spice of life: One-stage or two-stage repair of extensive chronic thoracic aortic dissection
}

\author{
Ourania Preventza, MD, ${ }^{\mathrm{a}, \mathrm{b}, \mathrm{c}}$ Vicente Orozco-Sevilla, MD, ${ }^{\mathrm{c}}$ Graham Pollock, $\mathrm{MD},{ }^{\mathrm{c}}$ and \\ Joseph S. Coselli, MD ${ }^{\mathrm{a}, \mathrm{b}, \mathrm{c}}$
}

From the ${ }^{\mathrm{a}}$ Department of Cardiovascular Surgery, Texas Heart Institute, Houston, Tex; ${ }^{\mathrm{b}}$ Department of Cardiovascular Surgery, CHI-Baylor St Luke's Medical Center, Houston, Tex; and ${ }^{\mathrm{c} D i v i s i o n}$ of Cardiothoracic Surgery, Michael E. DeBakey Department of Surgery, Baylor College of Medicine, Houston, Tex.

Disclosures: Dr Preventza participates in clinical trials for Vascutek Terumo and consults for and participates in clinical trials for Medtronic, Inc, and WL Gore \& Associates. Dr Coselli consults for, receives royalties and a departmental educational grant from, and participates in clinical trials for Vascutek Terumo and consults for and participates in clinical trials for Medtronic, Inc, and WL Gore \& Associates. All other authors have nothing to disclose with regard to commercial support.

Received for publication Nov 28, 2017; accepted for publication Dec 1, 2017; available ahead of print Jan 12, 2018 .

Address for reprints: Ourania Preventza, MD, One Baylor Plaza, BCM 390, Houston, TX 77030 (E-mail: opsmile01@aol.com).

J Thorac Cardiovasc Surg 2018;155:1936-7

$0022-5223 / \$ 36.00$

Copyright (c) 2017 by The American Association for Thoracic Surgery

https://doi.org/10.1016/j.jtcvs.2017.12.033

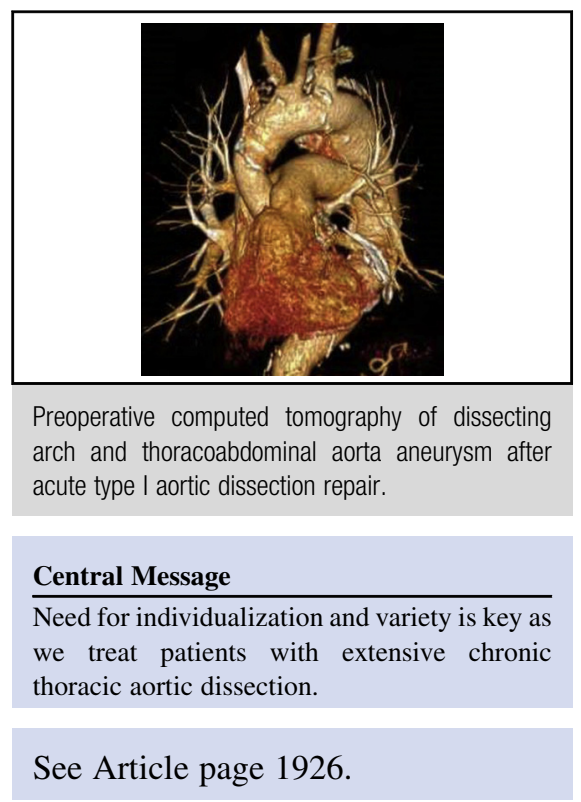

Extensive, 2-stage aortic replacement by the elephant trunk (ET) procedure was first described in 1983 by Borst and colleagues, ${ }^{1}$ who used the procedure to facilitate the replacement of the descending and thoracoabdominal aorta. The ET procedure has greatly facilitated the second stage, but the cumulative risk incurred by performing 2 major operations ${ }^{2}$ has created the need for a singlestage operation. Part of the argument for choosing the 1 -stage approach is avoiding aortic rupture and mortality between procedures ${ }^{3}$ and an almost guaranteed second reintervention. One-stage repairs could include the frozen ET (FET) procedure with a single-piece or custom-made device, and 1-stage open repair via bilateral anterior thoracotomy. Persistent patency of the distal false lumen, distal aortic dilation, and aneurysm formation are well-known potential sequelae that determine the fate of the distal dissected aorta.

We have to congratulate Dr Kouchoukos ${ }^{4}$ in this issue of the Journal for providing us with the largest series of chronic extensive thoracic aortic dissection repairs by a 1-stage technique via bilateral anterior thoracotomy. In this impressive work, 80 consecutive patients were treated for extensive chronic thoracic aortic dissection via a clamshell incision, with outstanding results. There is no question in anybody's mind that Dr Kouchoukos is a master surgeon with extensive experience. Replicating his results will be a challenging task. A hospital mortality rate of $2.5 \%$, stroke rate of $1.2 \%$, and spinal cord injury rate of $1.2 \%$ are outstanding results. Freedom from reoperation at 5 and 10 years was $89.2 \%$ and $84.4 \%$, respectively.

Despite these outstanding results, $42.5 \%$ of patients required ventilator support for more than 72 hours, and $15 \%$ needed tracheostomy. Older patients and patients

with poor pulmonary function or concomitant chronic obstructive pulmonary disease can better tolerate a single median sternotomy than any other incision with regard to pulmonary recovery. In contrast, younger and healthier patients tolerate most incisions equally well.

Also, among the patients treated in this report, the distal descending aorta did not exceed 4.5 to $5 \mathrm{~cm}$, so patients with mega-aorta and large (eg, extent II) thoracoabdominal aorta aneurysms were not treated with the described clamshell approach. Even for patients whose pathology extends no farther than the level of the diaphragm, what is wrong with a median sternotomy and a FET approach with an intent to treat the ascending aorta, arch, and descending thoracic aorta? For these patients, we currently favor using a stage 1 FET approach and to perform the completion stage 2 FET during the same hospital stay to avoid spinal cord injury. For patients whose pathology is limited to the upper descending thoracic aorta, we favor the 1-stage FET approach.

In addition, the report describes this approach in 13 patients $(16 \%)$ with connective tissue disorders. It is difficult to draw any conclusions from 13 patients alone. Finally, unlike median sternotomy, bilateral anterior thoracotomy is not in the routine repertoire of most cardiac surgeons. Individualization and variety are key as we treat these patients. 


\section{References}

1. Borst HG, Walterbusch G, Schaps D. Extensive aortic replacement using "elephant trunk" prosthesis. Thorac Cardiovasc Surg. 1983;31: 37-40.

2. Safi HJ, Miller CC III, Estrera AL, Villa MA, Goodrick JS, Porat E, et al. Optimization of aortic arch replacement: two-stage approach. Ann Thorac Surg. 2007;83: S815-8; discussion S24-31.

3. Etz CD, Plestis KA, Kari FA, Luehr M, Bodian CA, Spielvogel D, et al. Staged repair of thoracic and thoracoabdominal aortic aneurysms using the elephant trunk technique: a consecutive series of 215 first stage and 120 complete repairs. Eur J Cardiothorac Surg. 2008;34:605-15.

4. Kouchoukos NT, Kulik A, Castner CF. Clinical outcomes and rates of aortic growth and reoperation after 1 -stage repair of extensive chronic thoracic aortic dissection. J Thorac Cardiovasc Surg. 2018;155:192-35. 